\title{
Effect of Temperature, Wetness Duration, and Planting Density on Olive Anthracnose Caused by Colletotrichum spp.
}

\author{
Juan Moral, José Jurado-Bello, M. Isabel Sánchez, Rodrígues de Oliveira, and Antonio Trapero
}

First, second, third, and fifth authors: Departamento de Agronomía, ETSIAM, Universidad de Córdoba, Campus de Rabanales, Edif. C4, 14071 Córdoba, Spain; and fourth author: Faculdade de Ciências Agrarias, Universidade Agostinho Neto, 236 Huambo, Angola. Accepted for publication 15 June 2012.

\section{ABSTRACT}

Moral, J., Jurado-Bello, J., Sánchez, M. I., Oliveira, R., and Trapero, A. 2012. Effect of temperature, wetness duration, and planting density on olive anthracnose caused by Colletotrichum spp. Phytopathology 102: 974-981.

The influence of temperature, wetness duration, and planting density on infection of olive fruit by Colletotrichum acutatum and $C$. simmondsii was examined in laboratory and field experiments. Detached olive fruit of 'Arbequina', 'Hojiblanca', and 'Picual' were inoculated with conidia of several isolates of the pathogen and kept at constant temperatures of 5 to $35^{\circ} \mathrm{C}$ in humid chambers. Similarly, potted plants and stem cuttings with fruit were inoculated and subjected to wetness periods of 0 to $48 \mathrm{~h}$. Infection occurred at 10 to $25^{\circ} \mathrm{C}$, and disease severity was greater and the mean latent period was shorter at 17 to $20^{\circ} \mathrm{C}$. Overall, C. acutatum was more virulent than $C$. simmondsii at temperatures $<25^{\circ} \mathrm{C}$. When temperature was not a limiting factor, disease severity increased with the wetness period from 0 to $48 \mathrm{~h}$. Disease severity was modeled as a function of temperature and wetness duration; two critical fruit incidence thresholds were defined as 5 and $20 \%$, with wetness durations of 1.0 and $12.2 \mathrm{~h}$ at the optimum temperature. In the field, anthracnose epidemics progressed faster in a super-high-density planting (1,904 olive trees/ha) than in the high-density plantings (204 to 816 olive trees/ha) and caused severe epidemics in the super-high-density planting even with the moderately resistant Arbequina. Data in this study will be useful for the development of a forecasting system for olive anthracnose epidemics.
Anthracnose is the most important fruit disease of olive (Olea europaea) and is widespread in many olive-growing regions of the world, including southern Spain (20). Olive anthracnose is caused by two species of Colletotrichum, Colletotrichum acutatum J. H. Simmonds and C. gloeosporioides (Penz.) Penz. \& Sacc. (16,29). In Portugal and Spain, C. acutatum is the dominant species and C. gloeosporioides occurs infrequently $(16,23,29)$. Subsequent to the research cited previously in this paragraph, $C$. acutatum was reclassified as $C$. simmondsii, $C$. fioriniae, and $C$. acutatum sensu stricto (26). The teleomorphs of $C$. acutatum and C. gloeosporioides are known but have never been observed in olive orchards in southern Spain.

The pathogens mainly attack olive fruit, causing a typical rot called "soapy fruit" $(7,18)$. In Spain, $C$. acutatum produces toxins in the rotten fruit that cause leaf wilting and branch dieback several weeks after plants exhibit soapy fruit symptoms (20). In years when the disease is severe, anthracnose reduces yields by an average of $6 \%$ in Spain (7) and by up to $50 \%$ in other countries $(4,11,28,29)$. Field observations in southern Spain indicated that the disease is particularly severe in orchards that are densely planted with susceptible olive cultivars, although the effect of plant density has not been studied (31).

Much research has been conducted on olive anthracnose $(16,18,20,29)$ but little information exists on the effects of environment on disease epidemics. In addition to temperature and fruit maturity, rainfall is probably a critical factor in most olive anthracnose epidemics $(18,22,28)$. Most of this research has been done in the field, and information on the precise effects of

Corresponding author: A. Trapero; E-mail address: trapero@uco.es

* The $\boldsymbol{e}$-Xtra logo stands for "electronic extra" and indicates that the online version contains two supplemental figures.

http://dx.doi.org/10.1094/PHYTO-12-11-0343

(C) 2012 The American Phytopathological Society environmental variables on olive anthracnose under controlled conditions is scarce $(11,22,28)$. This information is required to understand and control many foliar pathogens, and is essential for the development of an infection submodel, a critical component in disease forecasting (14). For most fungal pathogens in most terrestrial environments, infection is usually limited by the duration of surface wetness or high humidity and temperature (5).

High production costs, especially for harvest, have resulted in the redesign of olive orchards, increasing plant density during the last 30 years. Traditional olive orchards in Spain had a relatively low density of trees ( 70 to 80 trees/ha and 2 to 3 trunks/tree). Modern olive oil producers are planting trees (1 trunk/tree) at 200 to 400 trees/ha in high-density systems. In the last 15 years, planting density has reached 2,000 trees/ha in superhigh-density systems in which the trees form hedgerows (2,24). These increased tree densities may favor the development of epidemics of airborne pathogens by increasing the duration of wetness on the leaves and fruit.

Knowledge of environmental and agronomic influences on disease development is important for the proper timing of fungicide applications for control of olive anthracnose. Precise information could aid in developing models that predict the development of epidemics during the autumn. Thus, the objectives of this work were to determine the influence of temperature and wetness duration on fruit on infection by Colletotrichum spp. and to determine the effect of tree density on the incidence of affected fruit.

\section{MATERIALS AND METHODS}

Fruit, potted plants, and stem cuttings. Three commercial olive cultivars with different degrees of resistance to anthracnose (21) were used: 'Hojiblanca' (susceptible), 'Arbequina' (moderately susceptible), and 'Picual' (resistant). These cultivars also differ in their time of ripeness, having been classified as late, medium, and early, respectively $(21,25)$. Olive fruit were collected from healthy 
field-grown trees in the provinces of Córdoba and Jaén (Andalusian region, southern Spain). Depending on the experiment and trial within experiment (these are described later in the Methods), the fruit used were green, green-yellow, or black with values of 0,1 , or 4 , respectively, according to the 0 to 4 ripening index (25). Olive fruit were washed in tap water, surface sterilized in a $10 \%$ solution of commercial bleach $(50 \mathrm{~g}$ of $\mathrm{Cl} /$ liter) for $1 \mathrm{~min}$, rinsed with sterile water, and air dried on a laboratory bench. Disinfested fruit were placed in plastic containers and stored at $4^{\circ} \mathrm{C}$ until used (within 7 days). Disinfested fruit were preconditioned at room temperature $\left(23 \pm 2{ }^{\circ} \mathrm{C}\right)$ for 4 to $6 \mathrm{~h}$ before inoculation with isolates of Colletotrichum (18). In the wetnessduration experiment (experiment 2), 4-year-old potted olive plants of Hojiblanca and 2-year-old plants of Arbequina from a commercial nursery were used in trials 1 and 2, respectively. The age difference between the cultivars was due to the shorter nonproductive period for Arbequina than for Hojiblanca $(2,25)$. Plants were grown in natural soil in 7-liter plastic containers until they were used in experiments. Plants were fertilized once $(7 \mathrm{~g}$ of $\mathrm{P}_{2} \mathrm{O}_{5}+2 \mathrm{~g}$ of $\mathrm{KNO}_{3}+1 \mathrm{~g}$ of $\mathrm{CaCO}_{3}+1 \mathrm{~g}$ of $\mathrm{MgSO}_{4}+0.6 \mathrm{~g}$ of $\mathrm{MgCO}_{3}$ per plant) and irrigated as needed. In trial 3 of the wetness-duration experiment, 30 - to $40-\mathrm{cm}$ pieces of stem with 5 to 15 olive fruit were cut from healthy field-grown trees of Arbequina in Córdoba. The stems were planted in moist, sterilized perlite in plastic boxes $(60$ by 40 by $20 \mathrm{~cm}$ ) to prevent dehydration of fruit before inoculation.

Fungal isolates. Isolates Col-09, Col-30, Col-87, and Col-104 were obtained from fruit on diseased olive trees from different orchards in the Andalusian region. The selected isolates represented the range of morphological characteristics typical of olive anthracnose pathogens. Isolates Col-09 and Col-30 had morphological characteristics similar to those of $C$. acutatum and $C$. gloeosporioides, respectively. Isolates Col-87 and Col-104, in contrast, exhibited morphological and physiological characteristics intermediate between these species (23). All isolates were identified as $C$. acutatum-group A4 by their internal transcribed spacer 5.8S and $\beta$-tubulin regions (29); $C$. acutatum-group A4 is the dominant group in central Andalusia (J. Moral and A. Trapero, unpublished data). The Italian isolate Col-116 (Monte Falco, Perugia region, Italy) was also used in some experiments. Based on molecular data, this isolate was identified as $C$. acutatumgroup A2, which is prevalent in Portugal (29); however, $C$. acutatum-group $\mathrm{A} 2$ has been subsequently reclassified as $C$. simmondsii (26). Single-spore isolates were cultured in petri dishes containing potato dextrose agar (PDA) (Difco Laboratories, Detroit) acidified with lactic acid (25\% [vol/vol] at 2.5 $\mathrm{ml} / \mathrm{liter}$ of medium). Cultures were incubated at $23 \pm 2{ }^{\circ} \mathrm{C}$ with a 12-h photoperiod of fluorescent light $\left(350 \mu \mathrm{mol} \mathrm{m} \mathrm{m}^{-2} \mathrm{~s}^{-1}\right)$ for 1 week. To ensure that the conidia used were viable, we measured the germination of each batch of inoculum before inoculation. The density of conidia in the inoculum was measured with a hemacytometer and was then diluted to $10^{5}$ conidia $/ \mathrm{ml}$.

Inoculation and incubation. Detached fruit and plants were sprayed to incipient runoff with the conidial suspension using an electric sprayer (Black \& Decker 58-102). Noninoculated controls for detached fruit or plants were sprayed with distilled water plus $0.02 \%$ Tween 20 .

Incubation treatments differed among experiments. Detached olives (experiment 1) were maintained in humid (100\% relative humidity $[\mathrm{RH}]$ ) plastic containers $\left(22\right.$ by 16 by $10 \mathrm{~cm}^{3}$ ) that were placed in growth chambers at different temperatures in the dark until the end of experiment. In general, plants and stem cuttings (experiment 2) were incubated during the "wetness period" in moist chambers that consisted of closed, dark-plastic boxes containing plastic pans filled with water to provide $100 \% \mathrm{RH}$. After the wetness period, inoculated plants and stem cuttings were dried at room temperature $\left(22 \pm 2{ }^{\circ} \mathrm{C}\right)$. The stem cuttings were then transferred to a growth chamber at $20^{\circ} \mathrm{C}$ for 4 days in the dark and then in fluorescent light with a 14-h photoperiod and 50 to $90 \% \mathrm{RH}$. The plants were transferred to the greenhouse at 15 to $30^{\circ} \mathrm{C}$ and $\mathrm{RH}<70 \%$ after the wetness period.

Effect of temperature on infection of detached fruit (experiment 1). Trial 1. Ripe, black fruit (ripening index value of 4) of Hojiblanca were inoculated with isolates Col-09 and Col-30 and kept in humid chambers. The humid chambers were placed in darkened growth chambers at $5,10,15,20,25,30$, and $35^{\circ} \mathrm{C}$. A disease severity index (DSI) was recorded at 7, 10, and 14 days after inoculation. The DSI was calculated for each replicate with the formula $D S I=\left(\sum n_{s} \times s\right) / N$, where $s$ represents severity (0 to $5), n_{s}$ is the number of fruit with the severity of $s$, and $N$ is the total number of fruit (18). Rating scale values were $0=$ no visible symptoms; $1=$ visible symptoms affecting $<25 \%$ of the fruit surface; and $2=25$ to $50 \%, 3=50$ to $75 \%, 4=75$ to $100 \%$, and 5 = fruit completely rotted, with abundant conidia in a gelatinous matrix (soapy fruit) (18). There were three replicate humid chambers ( 25 fruit/chamber) for each combination of isolate and temperature and the experiment was conducted three times. A split-plot design was used with experiment runs as blocks, temperature as main plot, isolate as subplot, and humid chambers as replications.

Trial 2. Green-yellow fruit (ripening index value of 1) of Hojiblanca and Picual were inoculated with isolates Col-104 and Col-116 and placed in humid chambers as described above. The DSI was recorded weekly for 6 weeks. For each temperature, DSI values were regressed against time with the formula $D S I=b \times t$, where $t=$ time in days and $b=$ symptom development rate $\left(\right.$ day $\left.^{-1}\right)$. For each temperature, a mean latent period (MLP) was calculated with the following formula:

$$
\operatorname{MLP}=\left(\Sigma \Delta I_{i} \times t_{\text {avg }}\right) / I_{\max }
$$

where $\Delta I_{i}=I_{i+1}-I_{i}$ is the increase in the percentage of symptomatic fruit at each interval, $t_{\text {avg }}=\left(t_{i+1}+t_{i}\right) / 2$ is the average number of days for each time interval, and $I_{\max }$ is the percentage of symptomatic fruit for each temperature at the maximum incubation period ( 6 weeks). Each isolate-temperature combination was represented by three humid chambers and the experiment was conducted three times. For each cultivar, a randomized complete block design was used with experiment runs as blocks, temperature as the independent variable, and humid chambers as replications.

Trial 3. This trial was identical to trial 2 except that, after inoculation, the fruit were incubated at the optimum temperature of $20^{\circ} \mathrm{C}$ for $48 \mathrm{~h}$ to ensure infection and then incubated at final temperatures of 5 to $35^{\circ} \mathrm{C}$ as described above.

Effect of wetness duration on infection of attached fruit (experiment 2). Trial 1. Four-year-old olive plants of Hojiblanca with green fruit (ripening index value of 0 ) were inoculated with isolate Col-87 as described above during September. The plants were placed in moist chambers in darkened growth chambers at $20^{\circ} \mathrm{C}$. Plants were subjected to 0-, 6-, 12-, 24-, or 48-h wetness periods. At the end of the wetness period, plants were removed from the moisture chambers, dried for $30 \mathrm{~min}$, and then moved to the greenhouse as described above. Additionally, three inoculated plants were dried immediately after inoculation at $22^{\circ} \mathrm{C}$ for $48 \mathrm{~h}$ and transferred to moist chambers for $48 \mathrm{~h}$ before they were transferred to the greenhouse to serve as a 48 -h-dry plus 48 -hwetness-period treatment. DSI was recorded weekly for 4 months. For each wetness period and replication, the relative area under the disease progress curve was calculated by trapezoidal integration of DSI values over time, expressed as a percentage of a maximum theoretical curve in which all fruit reached the severity value 51 week after inoculation (18). Five plants were subjected to each wetness period and the experiment was conducted two times. A randomized complete block design was used with experiment runs as blocks, wetness period as the independent variable, and olive plants as replications. 
Trial 2. Two-year-old plants of Arbequina with 20 to 25 greenyellow fruit (value 1 in the ripening index) were inoculated in November with isolate Col-87. Plants were subjected to 0-, 1.5-, $3-, 6-, 12-, 24-$, or 48-h wetness periods and incubated as described above. Fruit were collected 6 weeks after inoculation because most did not show any anthracnose symptoms. The percentage of fruit with latent infections of $C$. acutatum was determined using the herbicide $\mathrm{N}, \mathrm{N}^{\prime}$-dimethyl-4,4'-bipyridinium dichloride (Paraquat). For each sample, fruit were washed with sterile-distilled water for $30 \mathrm{~min}$, surface disinfested by successive immersion in $70 \%$ ethanol for $2 \mathrm{~min}$ and in a $20 \%$ solution of commercial bleach $(50 \mathrm{~g}$ of $\mathrm{Cl} /$ liter) in sterile water for $7 \mathrm{~min}$, rinsed with sterile water, and dipped in Paraquat (Paratex, 200 g/liter; Aragonesas Agro S.A., Madrid, Spain) at 2.9 g/liter of water for $1 \mathrm{~min}$ (20). The herbicide killed the fruit cells and thereby permitted rapid colonization by latent fungal propagules. Treated fruit were incubated at $22 \pm 2^{\circ} \mathrm{C}$ in humid chambers in the dark for 2 weeks and then fruit with anthracnose symptoms were counted. Five plants were subjected to each wetness period and the experiment was conducted two times. A randomized complete block design was used with experiment runs as blocks, wetness period as the independent variable, and olive plants as replications.

Trial 3. Because the fruit from noninoculated (control) potted plants in trial 2 of this experiment showed latent infection by the pathogen, the trial was repeated using stem cuttings from healthy trees of Arbequina with green-yellow fruit. The same isolates and wetness-duration treatments as those utilized in trial 2 were used. The inoculated stem cuttings were incubated at $23 \pm 2{ }^{\circ} \mathrm{C}$ and 50 to $90 \%$ RH with a 12 -h photoperiod of fluorescent light (350 $\mu \mathrm{mol} \mathrm{m} \mathrm{m}^{-2} \mathrm{~s}^{-1}$ ) for 2 weeks. Paraquat was used again to evaluate the percentage of infected fruit. Five stem cuttings were subjected to each wetness period and the experiment was conducted two times. A randomized complete block design was used with experiment runs as blocks, wetness period as the independent variable, and olive plants as replications.

Effect of planting density on incidence of affected fruit (experiment 3). Experiment 3 was conducted in a research orchard of Arbequina located in Córdoba province (latitude: $37^{\circ} 50^{\prime} \mathrm{N}$, longitude: $4^{\circ} 51^{\prime} \mathrm{W}, 91 \mathrm{~m}$ above mean sea level). The orchard, which belongs to the Andalusian Institute for Research and Formation in Agriculture and Fishery, is located near the Guadalquivir River in a humid area where anthracnose is an endemic disease. Trees were planted in 1999 at four densities: 3.5 $\mathrm{m}$ between rows and $1.5 \mathrm{~m}$ within rows (1,904 trees/ha), 3.5 by $3.5 \mathrm{~m}$ ( 816 trees/ha), 3.5 by $7.0 \mathrm{~m}$ (408 trees/ha), or 7.0 by $7.0 \mathrm{~m}$ (204 trees/ha) in a north-south orientation. The experiment was arranged in a randomized complete block design, with two olive rows of each planting density per block and four blocks in total. In November 2003, 500 fruit harvested from trees in each row (4,000 fruit per planting density) were arbitrarily selected and evaluated for symptoms of anthracnose. The effect of the height of fruit in the olive canopy was evaluated by harvesting 500 fruit at the $1.5-\mathrm{m}$ height and 500 fruit at the $3.0-\mathrm{m}$ height from each row of the highest planting density (1,904 trees/ha). In both cases, all fruit were evaluated for anthracnose symptoms. Nonsymptomatic fruit were incubated in a humid chamber $(100 \% \mathrm{RH})$ at $20^{\circ} \mathrm{C}$ in the dark to evaluate the incidence of latent infection. The experiment was repeated (trial 2) in November 2004.

Data analyses. Analysis of variance (ANOVA) was performed on disease incidence and severity data depending on the design of each experiment. All experiments and trials were repeated at least once, and data from repetitions of each experiment or trial were combined after checking for homogeneity of the experimental error variances by the $F$ test (two variances) or by the $\chi^{2}$ test (more than two variances). General ANOVAs were applied to the pooled data using experimental runs as blocks. Treatment means were compared by Fisher's protected least significant difference at $P=0.05$ for experiment 3 with categorical independent variables, whereas polynomial contrasts were used for quantitative independent variables (experiments 1 and 2). These polynomials were selected for subsequent regression analyses. In all experiments, data were tested for normality, homogeneity of variances, and pattern of residuals, which proved their suitability for the statistical analysis without data transformations. In the three trials of experiment 1 , the two cultivars were studied independently because they differ in susceptibility to anthracnose (21).

Regression analyses were applied to the pooled means of all independent quantitative variables. Various linear and nonlinear regression models were evaluated for describing the relationship between disease severity and temperature. The models tested were the generalized Analytis $\beta$ model (9), the Schödter angular model (9), and several second- or third-order polynomial equations based on results of ANOVA analysis. The Analytis $\beta$ model (9) was selected because it provided a good fit for all combinations of isolates and cultivars and because it has been used with other olive pathogens (32). The Analytis $\beta$ model uses the following equation:

$$
Y=k \times t^{a} \times(1-t)^{b}
$$

in which $Y=$ standardized disease severity $\left(Y=S / S_{\max }\right) ; t=$ standardized temperature $\left[\left(t=\left(T-T_{\min }\right) /\left(T_{\max }-T_{\min }\right)\right]\right.$; and $k, a$, and $b$ are unknown parameters. $T_{\min }$ and $T_{\max }$ were the minimum and maximum temperatures for infection. Linear regression was applied to test the relationship between data estimated by nonlinear regression and observed data. Parabolic curves $(Y=a+$ $b X+c X^{2}$ ) were fitted to the values MLP (day) versus temperature for each isolate, and the optimum temperatures were calculated in the fitted equations. Linear regression analysis was used to evaluate the relationship between wetness duration and the percentage of symptomatic fruit (with logarithmic transformation). When the fruit from noninoculated control plants from a commercial nursery showed quiescent infection, the mean value of infections among these controls was subtracted from the mean value on fruit from inoculated olive plants. In all cases, the best regression model was chosen from many combinations of terms based on the significance of the estimated parameters $(P \leq 0.05)$, Mallow's $C_{p}$ statistic, Akaike's information criterion modified for small data sets, the coefficient of determination $\left(R^{2}\right), R^{2}$ adjusted for degrees of freedom $\left(R_{a}^{2}\right)$, and the pattern of residuals over predicted and independent variables.

The results from the wetness-duration and temperature trials were used to develop an infection model according to Magarey et al. (15). The model of Magarey et al. (15) was used because we could not simultaneously control temperature and wetness with potted plants; the potted plants used in experiment 2 were too large for conventional temperature-controlled growth chambers.

According to the infection model of Magarey et al. (15), the wetness-duration requirement $\left(W_{(T)}\right)$ for the minimum disease threshold at temperature $T$ was calculated as

$$
W_{(T)}=\left[W_{\min } / f_{(T)}\right] \leq W_{\max }
$$

where $W_{(T)}=$ wetness-duration requirement (in hours) for the critical disease threshold at temperature $T, W_{\min }=$ the minimum value of the wetness-duration requirement for the minimum disease threshold at optimum temperature, and $f_{(T)}=$ temperature response function that varies from 0 to 1 ; when $f_{(T)}=0$ then $W_{(T)}=$ $W_{\max }$ and when $f_{(T)}=1$ then $W_{(T)}=W_{\min }(35)$. The temperature model uses a pathogen's cardinal temperatures to estimate the shape parameter and the temperature response:

$$
f_{(T)}=\left(\frac{T_{\max }-T}{T_{\max }-T_{o p t}}\right)\left(\frac{T-T_{\min }}{T_{o p t}-T_{\min }}\right)^{\left(T_{o p t}-T_{\min }\right) /\left(T_{\max }-T_{o p t}\right)}
$$


where $T=$ mean temperature $\left({ }^{\circ} \mathrm{C}\right)$ during the wetness period, $T_{\min }=$ minimum temperature for infection, $T_{\max }=$ maximum temperature for infection, and $T_{o p t}=$ optimum temperature for infection. Two critical disease thresholds of 10 and $20 \%$ of affected fruit were selected because a relatively low incidence of diseased fruit adversely affects the quality of olive oil (6). The model prediction was calculated in MS Excel (Microsoft, Redmond, WA). Data were analyzed using SPSS Software (version 14.0; SPSS Inc., Chicago).

\section{RESULTS}

Effect of temperature on infection of detached fruit (experiment 1). Trial 1. Both C. acutatum isolates (Col-09 and Col-30) caused anthracnose symptoms on black olive fruit of Hojiblanca at temperatures of 10 to $30^{\circ} \mathrm{C}$. The first symptoms on the fruit were observed 4 days after inoculation. Inoculated fruit incubated at $<25^{\circ} \mathrm{C}$ generally developed soapy rot symptoms with abundant production of conidia in a gelatinous matrix. However, when the fruit were incubated at 25 or $30^{\circ} \mathrm{C}$, the main symptom was fruit mummification. None of the noninoculated fruit developed anthracnose symptoms. The effect of isolate and the interaction between isolate and temperature on disease severity were highly significant $(P<0.0001)$. Isolate Col-09 was significantly $(P=0.0275)$ more virulent than Col-30 at $30^{\circ} \mathrm{C}$. The fitted Analytis $\beta$ models (Table 1) for each isolate are illustrated in Figure 1. All estimated parameters were significantly $>0(P<$ $0.0001), R^{2}$ and $R_{a}^{2}$ were $>0.85$, and the standardized residuals were randomly distributed over predicted $Y$ and $t$ for each isolate. There were significant $(P<0.0215)$ differences between the predicted temperatures of maximum disease severities, which were 24.1 and $20.2^{\circ} \mathrm{C}$ for isolates $\mathrm{Col}-09$ and Col-30, respectively (Table 1; Fig. 1).

Trial 2. Green-yellow olive fruit were susceptible to $C$. acutatum isolate Col-104 and C. simmondsii isolate Col-116. The first anthracnose symptoms were observed on fruit of Picual and Hojiblanca inoculated with $C$. acutatum at 14 and 21 days after inoculation, respectively. Both fungal species infected fruit at 10 to $25^{\circ} \mathrm{C}$. In addition, some fruit of Picual that were inoculated with $C$. acutatum developed disease symptoms at $5^{\circ} \mathrm{C}$, and $C$. simmondsii isolate Col-116 caused symptoms on some fruit of both cultivars at $30^{\circ} \mathrm{C}$ (Fig. 2). For both cultivars, the effect of species, temperature, and the species-temperature interaction on disease severity were highly significant $(P<0.001)$. Isolate Col104 was significantly $(P<0.05)$ more virulent than Col-116 at 10,15 , and $20^{\circ} \mathrm{C}$ on both olive cultivars. The Analytis $\beta$ model well described the relationship between temperature and disease severity (Fig. 2). For all species-cultivar combinations, $P$ was $<$
$0.0001, R^{2}$ and $R_{\mathrm{a}}{ }^{2}$ were $>0.90$, and the standardized residuals were randomly distributed over predicted $Y$ and $t$. The predicted temperature of maximum disease severity was 17.0 to $20.4^{\circ} \mathrm{C}$, depending on the combination species and cultivar (Table 1). When the latent period was studied, Col-116 was less affected by temperature than Col-104 (Fig. 2). At the optimum temperature, the MLP ranged from 19.5 days (for the combination of resistant Picual and Col-116) to 26.1 days (for the combination of susceptible Hojiblanca and Col-104). When fruit inoculated with Col104 were incubated at 10 or $30^{\circ} \mathrm{C}$, the MLP increased from 5 to 10 days.

Trial 3. When the inoculated fruit were pre-incubated at $20^{\circ} \mathrm{C}$ for $24 \mathrm{~h}$, the results were similar to those in trial 2, although both isolates caused little infection on the fruit of Hojiblanca at $35^{\circ} \mathrm{C}$. C. acutatum isolate Col-104 was more virulent on olive fruit than C. simmondsii isolate Col-116 at low temperatures $\left(<20^{\circ} \mathrm{C}\right)$ (Table 1).

Effect of wetness duration on infection on attached fruit (experiment 2). Trial 1. Typical anthracnose symptoms were observed at 8 weeks after inoculation on all treatments, which coincided with the onset of fruit ripening and change in fruit color from green to green-yellow. In general, the symptoms progressed

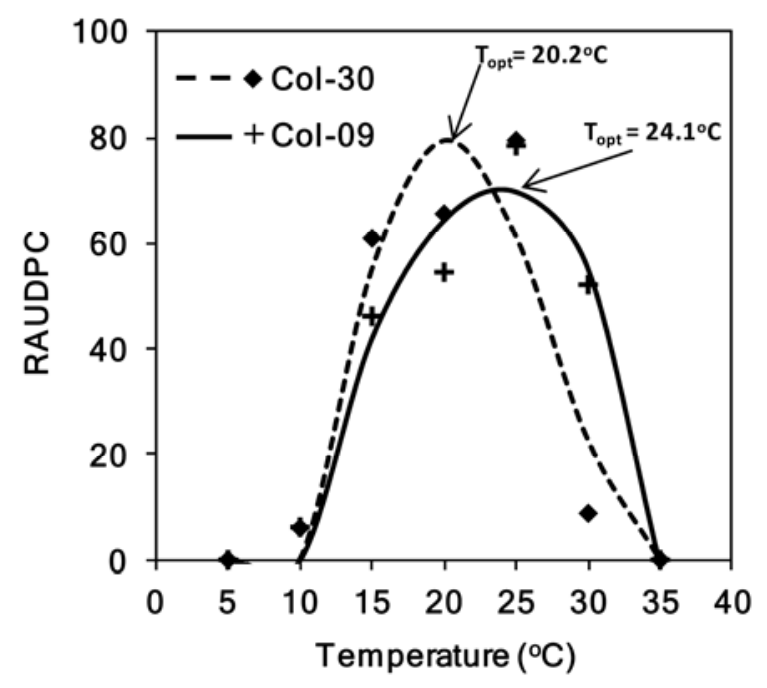

Fig. 1. Effect of temperature on the relative area under the disease progress curve (RAUDPC) for black olive fruit of 'Hojiblanca' inoculated with two isolates of Colletotrichum acutatum (experiment 1). Points represent the average of nine plastic boxes of 25 fruit each. Curves represent the Analytis $\beta$ functions, $Y=k \times t^{a} \times(1-t)^{b}$, relating the RAUDPC to temperature for each Colletotrichum isolate. Equations fit the observed data with $R^{2}>0.85$.

TABLE 1. Effect of temperature on disease severity on detached olive fruit inoculated with Colletotrichum spp. (experiment 1$)^{\mathrm{a}}$

\begin{tabular}{|c|c|c|c|c|c|c|c|c|c|}
\hline \multirow[b]{2}{*}{ Trial } & \multirow[b]{2}{*}{ Isolate } & \multirow[b]{2}{*}{ Species } & \multirow[b]{2}{*}{ Cultivar } & \multirow[b]{2}{*}{ Ripening $^{\mathrm{b}}$} & \multicolumn{4}{|c|}{ Analytis $\beta$ model parameters ${ }^{\mathrm{c}}$} & \multirow[b]{2}{*}{$T_{\text {opt }}\left({ }^{\circ} \mathrm{C}\right)^{\mathrm{d}}$} \\
\hline & & & & & $K$ & $a$ & $b$ & $R^{2}$ & \\
\hline 1 & Col-09 & Colletotrichum acutatum & Hojiblanca & Black (4) & 2.265 & 0.908 & 0.706 & 0.962 & 24.1 \\
\hline 1 & Col-30 & C. acutatum & Hojiblanca & Black (4) & 8.129 & 1.354 & 1.988 & 0.891 & 20.2 \\
\hline 2 & Col-104 & C. acutatum & Hojiblanca & Green-yellow (1) & 5.293 & 1.304 & 1.240 & 0.992 & 20.4 \\
\hline 2 & Col-104 & C. acutatum & Picual & Green-yellow (1) & 3.446 & 0.801 & 1.201 & 0.929 & 17.0 \\
\hline 2 & Col-116 & C. simmondsii & Hojiblanca & Green-yellow (1) & 47.839 & 3.024 & 3.354 & 0.985 & 19.2 \\
\hline 2 & Col-116 & C. simmondsii & Picual & Green-yellow (1) & 7.531 & 1.572 & 2.151 & 0.937 & 17.7 \\
\hline 3 & Col-104 & C. acutatum & Hojiblanca & Green-yellow (1) & 5.876 & 1.084 & 1.745 & 0.897 & 16.5 \\
\hline 3 & Col-104 & C. acutatum & Picual & Green-yellow (1) & 5.710 & 1.060 & 1.683 & 0.981 & 15.6 \\
\hline 3 & Col-116 & C. simmondsii & Hojiblanca & Green-yellow (1) & 23.47 & 2.118 & 2.407 & 0.957 & 19.0 \\
\hline 3 & Col-116 & C. simmondsii & Picual & Green-yellow (1) & 2.187 & 1.002 & 0.936 & 0.912 & 18.1 \\
\hline
\end{tabular}

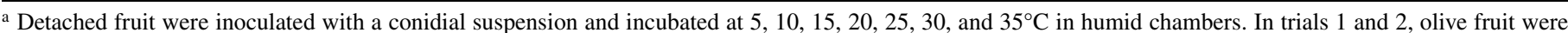

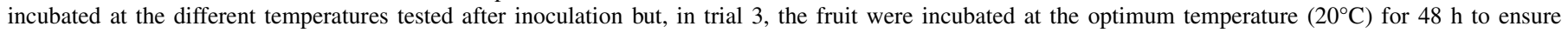
infection and then they were incubated at final temperatures tested.

${ }^{\mathrm{b}}$ Fruit ripening scale from color class green (0) to black (4) according to Rallo et al. (25).

${ }^{\mathrm{c}}$ Disease severity $(Y)$ and temperature $(t)$ data were adjusted to a nonlinear Analytis $\beta$ model $Y=k \times t^{a} \times(1-t)^{b}(9)$.

d Optimum temperature for infection. 
until the entire surface of the fruit was covered with the mycelia and acervuli of the pathogen. None of the fruit on noninoculated plants developed anthracnose symptoms. The pathogen caused fruit rot at all incubation periods, including the 0 -h treatment. Wetness period significantly $(P<0.0001)$ affected disease severity. There were three homogeneous groups, depending on disease severity. One group included wetness periods of 0 to $24 \mathrm{~h}$ and resulted in an average disease severity of $\approx 22 \%$. Other group that included the 48 -h wetness period resulted in a disease severity of $58.4 \%$. Finally, the plants that were subjected to a 48-h dry period after inoculation and were subsequently placed at $100 \% \mathrm{RH}$ for $48 \mathrm{~h}$ had a disease severity of $43.5 \%$.

Trial 2. When olive plants of Arbequina were inoculated, some fruit showed visible symptoms of anthracnose in the plant canopy 1 month after inoculation, even though most fruit showed anthracnose symptoms when they were treated with Paraquat and incubated in humid chambers. It is worth noting that $\approx 2.5 \%$ of the fruit that came from noninoculated control plants growing in commercial nurseries showed latent infection of the pathogen. The percentage of affected fruit increased log-linearly with increasing wetness duration from 0 to $48 \mathrm{~h}$ (Fig. 3A). The lowest wetness duration that resulted in disease development was the 0 -h treatment, with an incidence of $\approx 5 \%$. However, when the wetness duration was $48 \mathrm{~h}$, the disease incidence was $\approx 50 \%$.

Trial 3. In this trial, olive shoots of Arbequina were used to avoid natural latent infection by the pathogen. In this case, the initial symptoms of anthracnose were observed 1 week after inoculation. The percentage of affected fruit increased loglinearly, with increasing wetness duration between 0 and $48 \mathrm{~h}$ (Fig. 3B).

The results of the temperature and wetness experiment were used to develop an infection model for $C$. acutatum in the
Andalusian region, with $T_{\min }, T_{\max }$, and $T_{\text {opt }}$ of 10,25 , and $20.4^{\circ} \mathrm{C}$, respectively. At the optimum temperature, the two thresholds of 5 and $20 \%$ of affected fruit corresponded to wetness-duration periods of 1.0 and $12.2 \mathrm{~h}$, respectively (Fig. 4).

Effect of planting density on incidence of affected fruit (experiment 3). A significant anthracnose epidemic developed in the research orchard in 2003, when trial 1 of experiment 3 was conducted. The percentage of affected fruit was 12.2 to $95.2 \%$. The effect of planting density on the percentages of symptomatic fruit and latent infections was highly significant $(P<0.0001)$, whereas it had no influence $(P=0.234)$ on total infection (i.e., the number of affected fruit plus fruit with latent infections) (Fig. $5)$. The percentage of affected fruit was higher $(P<0.0001)$ in the highest-density planting $(1,904$ trees/ha) than with the other three planting densities, among which the percentage did not differ (Fig. 5). Consistent with this, the percentage of fruit with latent infections was significantly $(P<0.0001)$ lower with the highestdensity planting than with the other three planting densities (Fig. $5)$. The percentages of affected fruit and latent infections were significantly $(P<0.05)$ affected by the height of fruit in the olive canopy in the densest planting; the percentages were higher for fruit collected from the lower canopy $(1.5 \mathrm{~m})$ than for fruit from the top ( $3 \mathrm{~m}$ ) of the canopy (47.6 versus $26.8 \%$ ). In addition, fruit from the top of the canopy had more latent infections $(53.7 \%)$ than those from the lower canopy $(26.8 \%)$, although fruit height did not significantly affect $(P=0.460)$ total infection (Fig. 6).

\section{DISCUSSION}

In this study, the temperature and wetness durations that favored the development of olive anthracnose caused by Colletotrichum spp. were defined using the three main olive cultivars
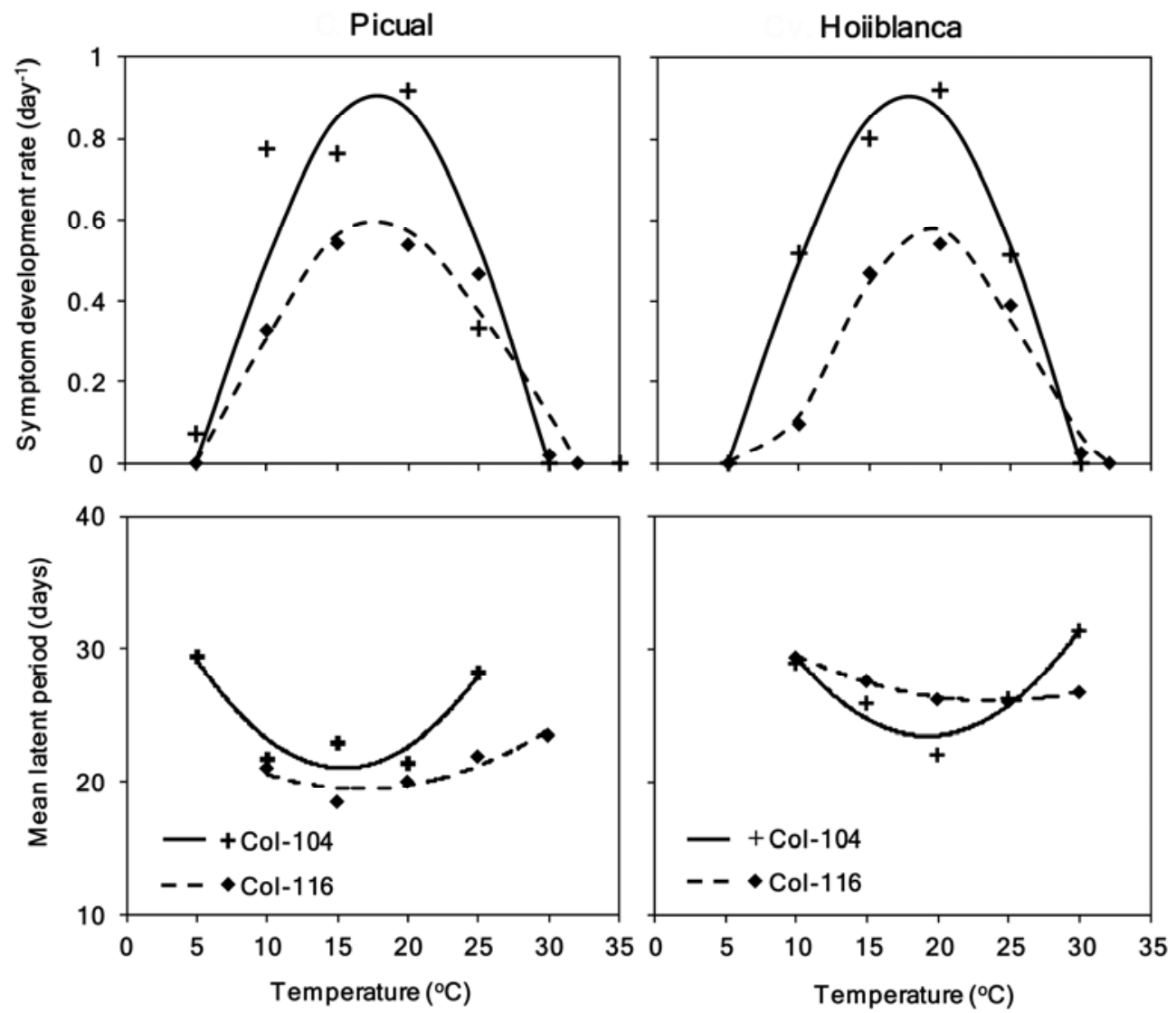

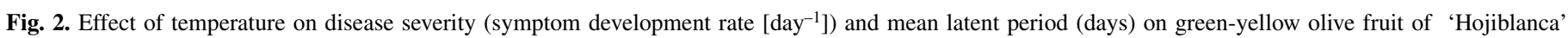

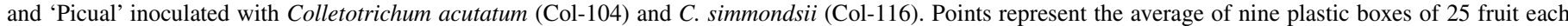

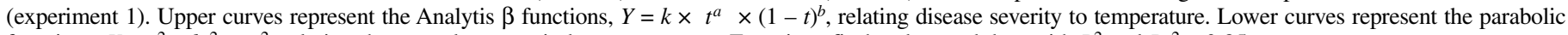
functions, $Y=a^{2}+b t^{2}+c t^{2}$, relating the mean latent period to temperature. Equations fit the observed data with $R^{2}$ and $R_{a}{ }^{2}>0.85$. 
currently planted in Spain (2) and several Colletotrichum isolates that belong to the genetic groups A2 and A4. The latter groups represent the dominant isolates in Portugal and in the central Andalusian region of southern Spain, respectively (29) (J. Moral
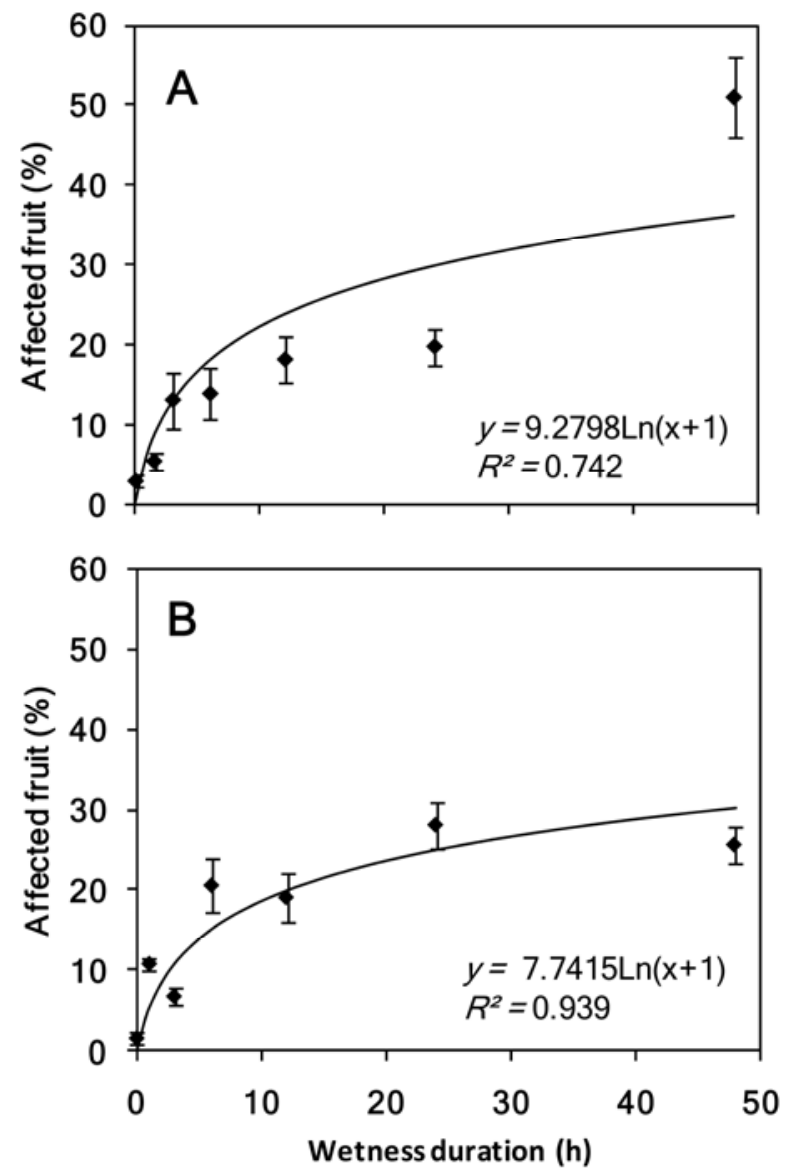

Fig. 3. Regression of wetness duration (h) on the incidence (\%) of olive anthracnose on fruit caused by Colletotrichum acutatum (experiment 2). Percentage of symptomatic fruit on $\mathbf{A}$, inoculated plants and $\mathbf{B}$, inoculated stem cuttings of 'Arbequina'. Points represent the average of 10 potted olive plants (A) or stem cuttings (B), each with 20 to 25 fruit. Bars represent the standard error of each mean.

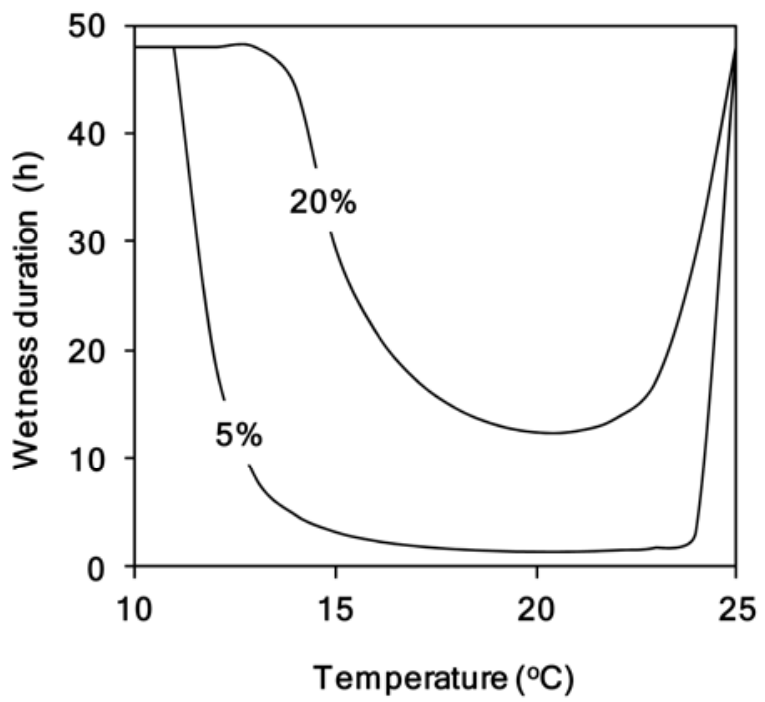

Fig. 4. Relative risk of infection of olive fruit by Colletotrichum acutatum based on wetness period $(W)$ and temperature $(T)$, as predicted by an infection model based on Magarey et al. (15). Upper and lower lines represent the contour plots for 5 and $20 \%$ disease incidence. and A. Trapero, unpublished data). Recently, C. acutatum groupA2 has been reclassified as the new species $C$. simmondsii (26). In all experiments, a reproducible method was used to inoculate olive plants and detached fruit with Colletotrichum spp. (18). This method has been previously used to assess cultivar resistance (21), pathogenic characteristics of the fungus (19), and virulence groups in the cultivar-isolate interaction (34).

Some important factors that affect anthracnose disease of olive (fruit maturity, inoculum dose, and cultivar resistance) were previously investigated in the development of the method to inoculate detached fruit and olive plants with Colletotrichum spp. $(18,21)$. In this study, some cultivars and fruit ripeness were included to have a wider response of disease severity to various temperatures and wetness durations. The infection of olive fruit

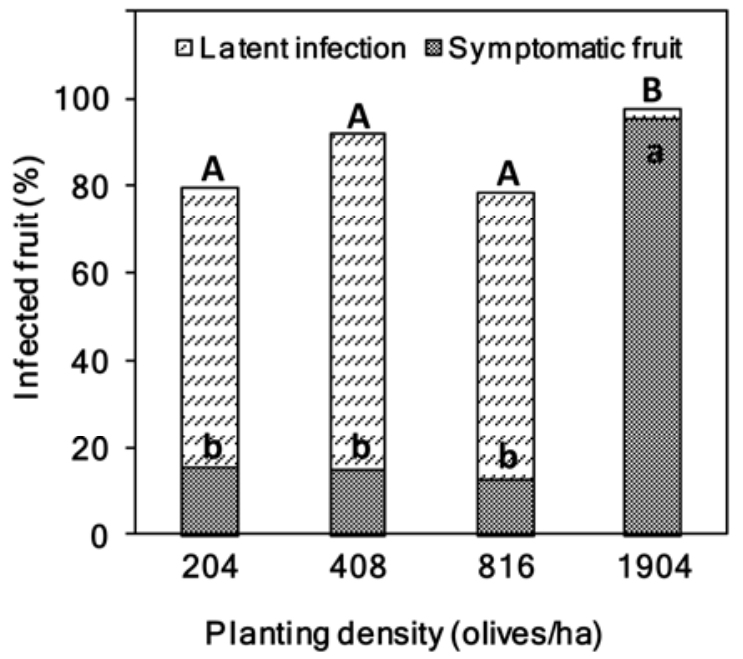

Fig. 5. Effect of olive tree density on incidence of symptomatic fruit (solid bar) and fruit with latent infection (striped bar) by Colletotrichum acutatum. Bars represent the average of 4,000 fruit at each tree density. Mean values of affected fruit (lowercase letters) or fruit with latent infection (uppercase letters) with the same letter are not significantly different according to Fisher's protected least significant difference test at $P=0.05$. Total fruit infection (based on fruit with symptoms plus fruit with latent infections; that is, the total height of the four bars) was not significantly affected $(P=0.234)$ by tree density.

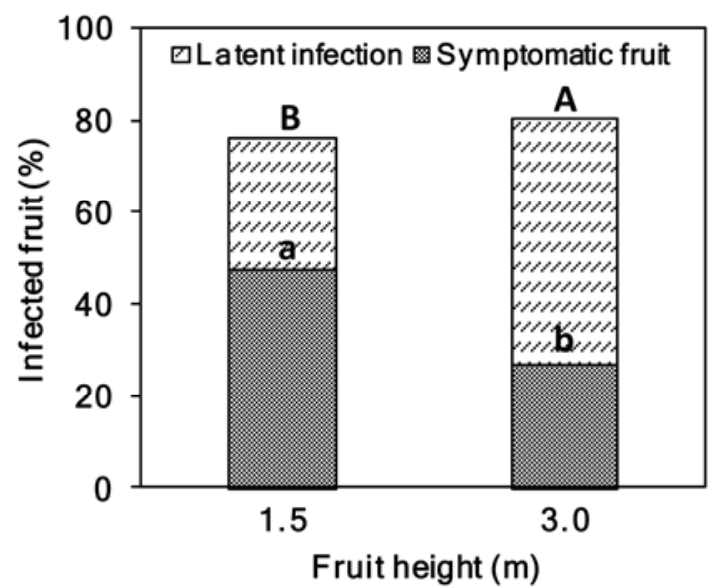

Fig. 6. Effect of fruit height (m) in the olive tree canopy on incidence of symptomatic fruit (solid bar) and fruit with latent infection (striped bar) by Colletotrichum acutatum. Bars represent the average of 2,000 fruit at each plant height. Mean values of affected fruit (lowercase letters) or fruit with latent infection (uppercase letters) with the same letter are not significantly different according to Fisher's protected least significant difference test at $P=$ 0.05 . Total fruit infection (based on fruit with symptoms plus fruit with latent infections; that is, the total height of the two bars) was not significantly affected $(P=0.460)$ by fruit height. 
by Colletotrichum spp. in the current study was influenced by temperature and wetness duration, which also influences infection in other Colletotrichum pathosystems $(8,12,33)$. When wetness was not a limiting factor, inoculation of detached fruit showed that infection occurred between 5 and $30^{\circ} \mathrm{C}$ but the incidence of infection was low at 5 and $30^{\circ} \mathrm{C}$ and was dependent on fungal isolate, cultivar, and fruit ripeness. The Analytis $\beta$ function was useful for describing the relationship between disease severity and temperature. According to this function, the optimum temperature for infection was 17.0 to $24.1^{\circ} \mathrm{C}$, depending on isolate and fruit ripeness. This value is within the optimal range of 20 to $24^{\circ} \mathrm{C}$ for germination of conidia $(10,23)$ and inoculum production from mummified olive fruit by C. acutatum isolates in Spain (22). Loprieno and Tenerini (13), in contrast, found an optimum temperature of 25 to $30^{\circ} \mathrm{C}$ for conidial germination of Italian isolates of the pathogen. Under field conditions, Kaul and Thakur (11) determined that the optimum temperature for olive leaf infection is 17 to $22^{\circ} \mathrm{C}$. These differences could be due to genetic variation within and among populations of Colletotrichum spp. that attack olive in different geographic regions. Molecular, physiological, and phenotypic analyses have revealed substantial diversity among olive isolates of Colletotrichum from Italy, Portugal, and Spain $(1,16,19,23,29)$. In the present study, at suboptimal temperatures for infection, latent periods increased substantially. Others have reported similar results with artificially inoculated olive fruit (13). This may explain why, when temperatures drop in the field during December, fruit with latent infections do not express anthracnose symptoms for several weeks (22).

In the detached-fruit experiment, anthracnose infection and development were similar for the resistant Picual and the susceptible Hojiblanca. The similar level of disease among these cultivars was probably due to the use of fruit that differed in ripeness; although the fruit color (green-yellow) indicated ripening stage 1 for both cultivars, the true ripening stage, based on the maturity of internal tissues (2), was probably higher for the more resistant Picual. This was suspected because many inoculated fruit of Picual quickly changed to a violet color (ripening stage 3). Differences between internal and external fruit ripening stages have been previously reported for other olive cultivars $(2,21)$.

For many foliar and fruit pathogens, an infection submodel is critical for disease forecasting (14) because infection is usually limited by the duration of surface wetness or high humidity $(15,17)$. When temperature was not a limiting factor, infections were detected at all wetness periods tested, even $0 \mathrm{~h}$, although the infection at this wetness period was low. The short time that elapsed from when the plants were inoculated until they were completely dry in the 0 -h treatment may have been sufficient for conidia to germinate, produce appressoria, and infect the fruit. In previous studies, conidial germination of $C$. acutatum isolates from olive was favored by an increase in the wetness duration, and $\approx 20 \%$ of the conidia germinated and formed appressoria within a 3 -h wetness period $(10,23)$. This represents a very short minimal wetness period for infection among foliar fungal pathogens. For example, the minimal wetness period for infection of olive leaves by Fusicladium oleagineum is $12 \mathrm{~h}$ (32).

In the wetness-duration experiment, disease severity increased with the wetness period from 0 to $48 \mathrm{~h}$, although this relationship was less clear when potted plants with developing fruit were inoculated during September, perhaps because of the effect of ripening. This is in accordance with the observation that, although the pathogen infects the developing olive fruit, the infections remain quiescent until the onset of ripening, when fruit color changes during the fall (20). When potted plants or stem cuttings with green-yellow fruit at the onset of ripening were inoculated, the incidence of symptomatic fruit increased logarithmically with the wetness duration. Similar effects of wetness period on disease development have been described for other hosts affected by $C$. acutatum $(8,33)$. It is interesting that, in our study, $2.5 \%$ of the fruit obtained from potted plants growing in a commercial nursery showed latent infections of the pathogen. Survival of Colletotrichum spp. on asymptomatic olive fruit could have implications for long-distance dissemination of the pathogen on potted plants.

Because the effects of wetness duration and temperature are interdependent, they should be considered together $(8,9,32,33)$. Using the generated data on the wetness-duration and temperature trials, we developed an infection model according to Margarey et al. (15) for the Andalusian region. The critical disease thresholds were defined as 5 and $20 \%$ of affected fruit because olive oil from fruit with $16 \%$ affected fruit loses the top quality classification (virgin extra) according to the European Community Regulations (6). This model was selected because it can use inputs based on independent temperature and wetness-duration trials and because it successfully described the relationship between temperature and wetness on disease infection on other Colletotrichum hosts (15). Unfortunately, the combined temperature and wetness-duration experiment is complicated on olive due to the large size of the adult potted plants and the inability to use detached fruit. Using preliminary data, we have found that the model is useful for describing the infection process during the high-risk months of October and November (22).

In the last decade, olive growers have tended to increase the density of trees in olive plantations from 70 to 100 trees/ha to $>2,000$ trees/ha $(2,24)$. For many pathosystems, microclimatic changes resulting from higher plant densities usually create conditions more conducive for disease development $(3,27)$. Increased plant density is likely to increase the duration of wetness on host tissues. Although the concept that growing plants in dense stands contributes to severe epidemics is an accepted axiom (3), it is supported by only limited experimental data. The current study is the first to document the effect of planting density on the development of olive anthracnose under field conditions. We observed that the percentage of affected fruit was highest in the densest plantings, although there was no difference among the planting densities on total fruit infection (symptomatic plus latent infections). This indicates that the epidemic progressed fastest in the densest plantings and that important anthracnose epidemics may develop in dense planting even with a moderately resistant cultivar such as Arbequina (21). An increase in the incidence of olive leaf spot caused by $F$. oleagineum related to an increase in planting density has also been observed in olive orchards (30).

Results of the current study relating disease incidence and severity to temperature and wetness duration may be used to develop forecasting models for olive anthracnose. These models, however, should also take into account the dominant species of the pathogen, the resistance of the cultivars, and tree density.

\section{ACKNOWLEDGMENTS}

This research was funded by project P08-AGR-03635 of the Andalusian Regional Government (Spain). We thank the Spanish Agency for International Cooperation for granting R. de Oliveira a stay at the University of Córdoba for 3 years; the Andalusian Institute for Research and Formation in Agriculture and Fishery for the use of experimental orchards; M. Pastor and V. Vega, who were in charge of the experimental orchard; and W. J. Kaiser, B. A. Jaffee, T. J. Michailides, and J. V. Giráldez for critical review of the manuscript.

\section{LITERATURE CITED}

1. Agosteo, G. E., Magnano di San Lio, G., Cacciola, S. O., and Frisullo, S. 2002. Characterisation of the causal agent of olive anthracnose in southern Italy. Acta Hortic. 586:713-716.

2. Barranco, D., Fernández-Escobar, R., and Rallo, L. 2010. Olive Growing. Junta de Andalucía/Mundi-Prensa/RIRDC/AOA, Pendle Hill, NSW, Australia.

3. Burdon, J. J., and Chilvers, G. A. 1982. Host density as a factor in plant disease ecology. Annu. Rev. Phytopathol. 20:143-166. 
4. Cacciola, S. O., Pane, A., Agosteo, G. E., and Magnano di San Lio, G. 1996. Osservazioni sull' epidemiologia dell'anthracnosi dell'olivo in Calabria. Inf. Fitopatol. 6:27-32.

5. Campbell, C. L., and Madden, L. V. 1990. Introduction to Plant Disease Epidemiology. John Willey \& Sons, New York.

6. Carvalho, M. T., Simões-Lopes, P., and Monteiro da Silva, M. J. 2004. Influence of different olive infection rates of Colletotrichum acutatum in some important olive oil chemical parameters. Acta Hortic. 791:57-59.

7. de Andrés, F. 1991. Enfermedades y Plagas del Olivo. Riquelme y Vargas Ediciones S.L., Jaén, Spain.

8. Diéguez-Uribeondo, J., Förster, H., and Adaskaveg, J. E. 2011. Effect of wetness duration and temperature on the development of anthracnose on selected almond tissues and comparison of cultivar susceptibility. Phytopathology 101:1013-1020.

9. Hau, B., and Kranz, J. 1990. Mathematics and statistics for analyses in epidemiology. Pages 15-22 in: Epidemics of Plant Diseases. J. Kranz, ed. Springer-Verlag, Berlin.

10. Jurado-Bello, J. 2010. Efecto de la temperatura, tiempo de humectación y potencial osmótico en la infección de aceitunas, germinación de conidios y crecimiento micelial de Colletotrichum spp. agente causal de la Antracnosis del olivo. Trabajo Profesional Fin de Carrera, ETSIAM, Universidad de Córdoba, Córdoba, Spain.

11. Kaul, J. L., and Thakur, R. S. 1985. Incidence of olive anthracnose (Colletotrichum gloeosporioides Penz.) and its correlation with weather conditions. J. Tree Sci. 4:20-34.

12. Leandro, L. F. S., Gleason, M. L., Nutter, F. W., Jr., Wegulo, S. N., and Dixon, P. M. 2003. Influence of temperature and wetness duration on conidia and appressoria of Colletotrichum acutatum on symptomless strawberry leaves. Phytopathology 93:513-520.

13. Loprieno, N., and Tenerini, I. 1960. Indagini sul Gloeosporium olivarum Alm., agente della "lebbra" delle olive. Phytopathol. Z. 39:262-290.

14. Madden, L. V., and Ellis, M. A. 1988. How to develop plant disease forecasters. Pages 191-208 in: Experimental Techniques in Plant Disease Epidemiology. J. Rotem, ed. Springer-Verlag, New York.

15. Magarey, R. D., Sutton, T. B., and Thayer, C. L. 2005. A simple generic infection model for foliar fungal plant pathogens. Phytopathology 95:92100.

16. Martín, M. P., and García-Figueres, F. 1999. Colletotrichum acutatum and C. gloeosporioides cause anthracnose on olives. Eur. J. Plant Pathol. 105:733-741.

17. Monroe, J. S., Santini, J. B., and Latin, R. 1997. A model defining the relationship between temperature and leaf wetness duration, and infection of watermelon by Colletotrichum orbiculare. Plant Dis. 81:739-742.

18. Moral, J., Bouhmidi, K., and Trapero, A. 2008. Influence of fruit maturity, cultivar susceptibility, and inoculation method on infection of olive fruit by Colletotrichum acutatum. Plant Dis. 92:1421-1426.

19. Moral, J., Oliveira, R., Tello, J. C., and Trapero, A. 2007. Caracterización fisiológica y patogénica de aislados de Colletotrichum spp. causantes de la Antracnosis del olivo. Bol. San. Veg. Plagas 33:219-234.

20. Moral, J., Oliveira, R., and Trapero, A. 2009. Elucidation of the disease cycle of olive anthracnose caused by Colletotrichum acutatum. Phytopathology 99:548-556.

21. Moral, J., and Trapero, A. 2009. Assessing the susceptibility of olive cultivars to anthracnose caused by Colletotrichum acutatum. Plant Dis. 93:1028-1036

22. Moral, J., and Trapero, A. 2012. Mummified fruit as a source of inoculum and disease dynamics of olive anthracnose caused by Colletotrichum spp. Phytopathology 102:982-989.

23. Oliveira, R., Moral, J., Bouhmidi, K., and Trapero, A. 2005. Caracterización morfológica y cultural de aislados de Colletotrichum spp. causantes de la Antracnosis del olivo. Bol. San. Veg. Plagas 31:531-548.

24. Pastor, M., Fereres, E., Vega, V., and Hidalgo, J. C. 2006. Viabilidad económica de plantaciones superintensivas en Andalucía. Vida Rural 238:60-66.

25. Rallo, L., Barranco, D., Caballero, J. M., del Río, C., Martín, A., Tous, J., and Trujillo, I., eds. 2005. Variedades de Olivo en España. Junta de Andalucía, M.A.P.A. \& Mundi-Prensa, Madrid.

26. Shivas, R. G., and Tan, Y. P. 2009. A taxonomic re-assessment of Colletotrichum acutatum, introducing $C$. fioriniae comb. et stat. nov. and C. simmondsii sp. nov. Fungal Divers. 39:111-122.

27. Strandberg, J. O., and White, J. M. 1978. Cercospora apii damage of celery: Effects of plant spacing and growth on raised beds. Phytopathology 68:223-226.

28. Talhinhas, P., Mota-Capitão, C., Martins, S., Ramos, A. P., Neves-Martins, J., Guerra-Guimarães, L., Várzea, V., Silva, M. C., Sreenivasaprasad, S., and Oliveira, H. 2011. Epidemiology, histopathology and aetiology of olive anthracnose caused by Colletotrichum acutatum and $C$. gloeosporioides in Portugal. Plant Pathol. 60:483-495.

29. Talhinhas, P., Sreenivasaprasad, S., Neves-Martins, J., and Oliveira, H. 2005. Molecular and phenotypic analyses reveal association of diverse Colletotrichum acutatum groups and a low level of C. gloeosporioides with olive anthracnose. Appl. Environ. Microbiol. 71:2987-2998.

30. Trapero, A. 2007. Densidad de plantación y enfermedades del olivar. Mercacei 51:210-213.

31. Trapero, A., and Blanco, M. A. 2010. Diseases. Pages 521-578 in: Olive Growing. D. Barranco, R. Fernández-Escobar, and L. Rallo, eds. Junta de Andalucía/Mundi-Prensa/RIRDC/AOA, Pendle Hill, NSW, Australia.

32. Viruega, J. R., Roca, L. F., Moral, J., and Trapero, A. 2011. Factors affecting infection and disease development on olive leaves inoculated with Fusicladium oleagineum. Plant Dis. 95:1139-1146.

33. Wilson, L. L., Madden, L. V., and Ellis, M. A. 1990. Influence of temperature and wetness duration on infection of immature and mature strawberry fruit by Colletotrichum acutatum. Phytopathology 80:111-116.

34. Xaviér, C. J. 2009. Resistencia y grupos de virulencia en la Antracnosis del olivo causada por Colletotrichum spp. Master's thesis, ETSIAM, Universidad de Córdoba, Córdoba, Spain.

35. Yin, X., Kropff, M. J., McLaren, G., and Visperas, R. M. 1995. A nonlinear model for crop development as a function of temperature. Agric. For. Meteorol. 77:1-16. 